\title{
塩素ガス中の水素の定量
}

\author{
下村 滋*，井口 正男**
}

\begin{abstract}
水素を含えだ塩素ガスに光化学反応活性の光をあて, $\mathrm{Cl}_{2}+\mathrm{H}_{2} \stackrel{\mathrm{h}}{\longrightarrow} 2 \mathrm{HCl}$ のように塩化水素ガスとし たのち赤外分光光度計で $2980 \mathrm{~cm}^{-1}$, または $2840 \mathrm{~cm}^{-1}$ を中心とする塩化水素に特有なきょ歯状の吸 収を測定し，基線法によって定量しようとする方法について検討した．との方法は水分ならびに二酸化 炭素ガスの影響を受けることなく, したがって電解塩素ガス中の水素の定量に適しており, 実際に電解 塩素製造工程中のガス分析を行なったが，いずれも爆発法による分析值些一致した。
\end{abstract}

1 緒 言

従来食塩電解工場において塩素ガス中の水素ガスを定 量する方法としては, 試料ガス中の塩素ガスを水酸化ナ トリウム，ヨウ化カリウム，またはチオ硫酸ナトリウム などの溶液で反応除去したのち, 爆発法, ならびにパラ ジウムアスベストまたは特殊な薬剤に吸収させるなどの 方法ぶとられている・しかしながらこれらの方法は連続 的に測定するととが不可能であり，食塩電解工程におい て混入する水素ガスの濃度变化を追跡することが困難で 岕る.また試料ガスに光化学反応活性の光を照射して塩 素と水素を塩化水素ガスとしたのち塩化水素ガスを選択 的に吸収するような液体で捕そく定量することはすでに 発表されている1)㣻，これも連続化すること泪困難であ る.

そこで迅速に精度よくかつ連続的に定量できる可能性 をすつ定量法として次の基礎実験を行なった。

すなわち, 試料の塩素ガスに光化学反応活性の光を照 射乙て反応させ, $\mathrm{Cl}_{2}+\mathrm{H}_{2} \stackrel{\mathrm{h} \nu}{\longrightarrow} 2 \mathrm{HCl}$ のように塩化水素 ガスとしたのち赤外分光光度計で波長 $2980 \mathrm{~cm}^{-1}$ または $2840 \mathrm{~cm}^{-1}$ を中心とした塩化水素洔有なきょ歯状の吸 收を描かせ，一方同様な方法で得られた検量線から定量 を行なうものであって，電解そうを出た塩素中にはこの 波長において妨害する物質もなく, からある程度の水 分, 炭酸ガスの混在においても定量可能である.

\section{2 装置および試料}

\section{$2 \cdot 1$ 装}

反応装置 : Fig. 1 に示し, その操作法については $3 \cdot 1$

* 德島大学薬学部: 德島市庄町 1 丁目

** 東亜合成化学工業株式会社德島工場 : 德島市川内町 中島
で述ベる。

ガス分析装置 : Orsat 装置とガラス製爆発ピペットを 組み合わせて用いた。すなわ台試料ガスをOrsatにとり 約 $25 \%$ 水酸化ナトリウムに吸収させたの方, 残ガスを 爆発ビニレットにとり, 清浄な空気を適当量加えたの方 白金線火花間げきに感応コイルより電気火花を与えて爆 発させ，六の減量より水素ガス濃度を算出するむのであ る。

赤外分光光度計：日立 EPI-2 型 $100 \mathrm{~mm}$ のガスセル に石英製の悹ガラスを付けて使用した。

水銀燈: $400 \mathrm{~W}$ 東芝 $\mathrm{H} 400 \mathrm{P}$ 型.

\section{2 試 料}

液体塩素：東亜合成工業株式会社 坂出工場で充てえ したもので，JIS K 1102 により定量したところヨウ化 カリウム液にほとえど吸収され残存のガスのない純度 99.9\% 以上のものを使用した.

水素 : 東亜合成德島工場で製造され新日本理化株式会 社德島工場で充てえしたもので，Rauter 分析計（三鷹 工業）により純度 $99.8 \%$ 以上の指示のものを使用し た。

\section{3 実験方法}

\section{1 反応装置の説明}

Fig. 1 は塩素ガスと水素ガスの濃度既知の混合ガスを つくり，それによって基礎研究を行なった装置の略図で あるが，以下その図に基づき説明する.

保安のためあらかじめ導管 aより窒素ガスを水素流通 経路に通じて装置内の空気を置換したのち，塩素ガスお よび水素ガスをそれぞれ導管より装置に導入する。これ らのガスはそれぞれT字管により二方に分けられ，一方 は圧力調節用びえ $\mathrm{c}, \mathrm{c}^{\prime}$ に導かれ, 余分なガスの塩素は約 $25 \%$ 水酸化ナトリウム溶液に吸収させ, 水素は大気中 


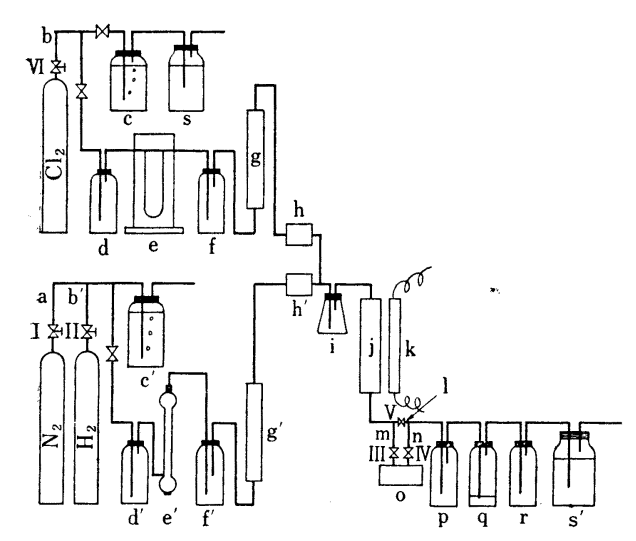

Fig. 1 Schematic diagram of reaction apparatus

$\mathrm{a}$ : Nitrogen gas inlet; $\quad \mathrm{b}$ : Chlorine gas inlet; $\mathrm{b}^{\prime}$ : Hydrogen gas inlet; $c, c^{\prime}$ : Pressure regulator; $d, d^{\prime}, f$, $\mathrm{f}^{\prime}, \mathrm{p}, \mathrm{r}$ : Gas washing-bottle, empty; e: Olifice meter, Daifloil \#1 (Daikin) was used; $\mathrm{e}^{\prime}$ : Soap-film flow meter; $\mathrm{g}, \mathrm{g}^{\prime}$ : Silica gel dryer; $\mathrm{h}, \mathrm{h}^{\prime}$ : Back stopper; $\mathrm{i}$ : Gas mixing bottle; $\mathrm{j}$ : Quartz reactor tube; $\mathrm{k}$ : 400W mercury lamp (Toshiba H400P); 1: Bypass; $\mathrm{m}, \mathrm{n}:$ Inlet and outlet of sample gases for I. R. cell; o: Gas cell, $100 \mathrm{~mm}$ pass; q : Gas washing-bottle (concentrated sulfuric acid); $s, s^{\prime}:$ Gas absorption bottle ( $25 \%$ sodium hydrochloride solution); I VI : Needle valve and stop cock

に流れ去るようにしてある。一方圧力調節びんには飽和 塩化ナトリウム溶液を入れ，それにそう入したガラス管 の深さによって流量を調節するが（本実験では塩素ガス を 860〜 $1000 \mathrm{ml} / \mathrm{min}$ で流した)，この深さによって 調 節されたガスは, 塩素ガスはマノメーター型オリフィス （ダイフロイル \#1 を使用）e で, 水素ガスは石けえ膜 流量計 $\mathrm{e}^{\prime}$ により流量が測定される. それぞれのガスは 逆流防止びん $f, f^{\prime}$, 乾燥塔 $g, g^{\prime}$, 逆流防止弁 $h, h^{\prime}$ を通 じて混合びえ i で混合される．混合されたガスは直径 $1 \mathrm{~cm}$, 長さ約 $30 \mathrm{~cm}$ の石英ガラス管 $\mathrm{j}$ を通過する際に 横から水銀燈によって照射され，塩化水素ガスとなる. そののち赤外用ガスセル ○中を流しガスセル中に捕そく する.

反応後の廃ガスは, 逆流防止びえ $\mathrm{p}, \mathrm{q}, \mathrm{r}$ を経て塩素 吸収のため $25 \%$ 水酸化ナトリウムを入れたびえを通し て大気中に流れ出る.なおガス採取以外のときのガスの 流通のためバイパス 1 を作っている.

\section{2 操 作}

Fig. 1 の装置を次のようにして操作した.

(1) 水素ガス導管 $b^{\prime}$ のバルブ (II) とガスセルoに連 結されたコック(III)，(IV)を閉じておき，それ以外の コックは開く.
(2) 呿素ガス a のバルブ (I) を開いて水素ガス流通経 路に窒素ガスを流し，装置内の空気を除いておく・この とき石けえ膜流量計 $\mathrm{e}^{\prime}$ と逆流防止びん $\mathrm{q}$ の濃硫酸によ りガスが流通しているかどうかを調べる.

(3) 装置内の空気が窒素でじゅうぶて置換されたらバ ルブ (I) を閉じる.

(4) 塩素ガス流通装置のコックをすべて開き, バルブ (VI) をあけ塩素ガスをマノメーター型オリフィス流量 計 e により一定量流す. 本実験は 860 $1000 \mathrm{ml} / \mathrm{min}$ 流 したが，このとき $\mathrm{e}$ q で塩素ガスが流れているかどう かを確認する。

(5) バルブ (II) を開いて水素ガスを所定の流量を流 す.このとき流量は石けん膜流量計で調べる.

(6) 塩素ガスと水素ガスの調節はそれぞれ圧力調節び ん c， c' にそう入されたガラス管の深さによって調節す る.そして両流量計の読みから水素ガスの濃度を計算す る.

(7) 導管 $\mathrm{m}$ にガス分析装置を連結し，水素ガス濃度を 爆発法で測定し，6による濃度と一致した值が得られる までガスを流す。

(8) 一致した值が得られたならばまず $\mathrm{m}, \mathrm{n}$ にガスセ ルを付け，未反応ガスを採取し暗所に保存する.

(9) ついで水銀燈 $\mathrm{k}$ を点燈し，反応を行なわせる.

(10) 水素ガスが完全に塩化水素になったころ，ふたた びガス分析を行ない，水素ガスの残っていないことを確 かめる。

(11) ガス分析装置をとり，赤外用ガスセル。を導管 $\mathrm{m}, \mathrm{n}$ に連結し，コック (III), (IV) を開き，(V) を閉じ てガスが o 中に流れるようにする。

(12) 0 に一定時間 ガスを流したのち（本実験では 10 分間）コックを元にもどし，ガスをバイパス 1 に流す.

(13) 一連の実験が終了すれば $\mathrm{k}$ の照射范止め, 水素ガ スを必ず先に止め，そののち增素ガスを止める.

なお，実験中に次の諸点を注意する必要があった。

（1）なるべく装置は直射日光を避け，特に混合びえ $\mathrm{i}$ 付近を絶縁テープでしゃ光した.

（2）両ガスは常に圧力調節びん $\mathrm{c}, \mathrm{c}^{\prime}$ よりオーバー フローした状態がよい。さもなければ一定した流量で動 かすことは不可能であった。

（3）廃ガス吸収びえ s では反応によって生じた結晶 性物質がたまり，特に管の先で詰まった際に装置が危険 であるので，管の先の詰まりを注意するとともに，実験 中はqにおけるバブリングの状態をいつも観察した。

（4）水素ガスの流量調節がよくないときは $\mathrm{d}^{\prime}$ の前 に温度計を切断して作った抵抗をそう入した。 
（5）爆発の危険から避けるため, 装置の前に透明の アクリル樹脂のつい立てを立て, 実験者はアクリル製防 爆用マスクをかぶって行なった。

\section{3 吸光度測定}

赤外用ガスセルに捕そくした反応後の試料ガスは, 赤 外分光光度計を用いて未反応のガスを入れたガスセルを 対照にし $3400 \sim 2400 \mathrm{~cm}^{-1}$ の間について吸収曲線を描 かせる. その1例を Fig. 2 に示したが, 短波長側の直 線をのばして基線とし $2980 \mathrm{~cm}^{-1}$ または $2840 \mathrm{~cm}^{-1}$ か ら基線法によってその位置における吸光度を算出する.

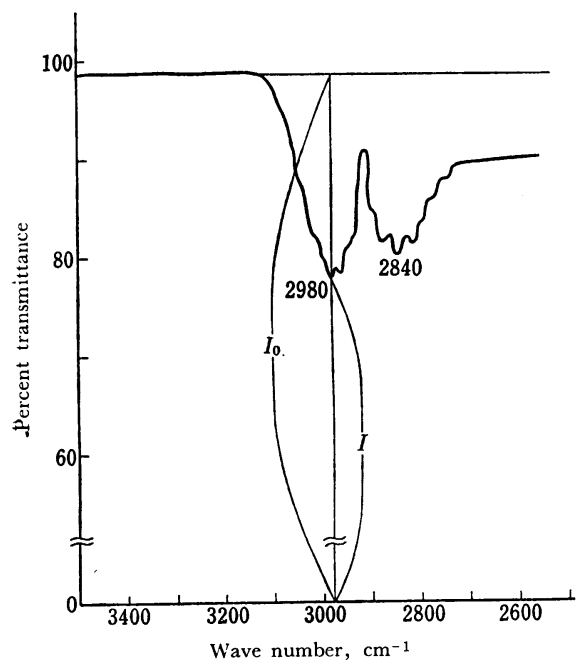

Fig. 2 Infrared absorption spectrum of hydrochloric gas

\section{4 水分の影響の検討}

水を含有することによりどのような影響を及ぼすかを 検討した. Fig.1 において水素ガス濃度を $2.00 \%$ に一 定に保ち，f, $\mathrm{f}^{\prime}$ に冷却トラップを入れたり，または乾燥 塔 $\mathrm{g}, \mathrm{g}$ を注ずしたりして水分の量を変化させたが，得 られた吸光度は $0.0573,0.0588,0.0588$ と変わらなか った。なおその際の水分含量は, 試料ガス中の水分を冷 却捕そくしたのちクロロホルムーエタノール混液で溶 出, その $1.9 \mu$ における吸光度から測定したが2)，そ れぞれ $7.1 \mu l / l, 6.5 \mu l / l, 8.2 \mu l / l$ であった。

\section{5 二酸化炭素の影響の検討}

食塩電解工程より発生する塩素ガスは, 水素ガスとと もに電極に使用する炭素が酸化されて生ずる二酸化炭素 を含有し，これは電解そうより出た塩素ガスの赤外吸呮
スペクトルを測定すれば $2320 \mathrm{~cm}^{-1}$ 付近に強い吸収が あるところからも明らかである.この二酸化炭素がこの 定量法にいかなる影響を及ぼすかを検討した。

すなわち, Fig. 1 において水素の流通装置と同様の装 置を組み, これを混合びえ $\mathrm{i} に$ 連結する. 塩素ガス, 水 素ガスを一定状態で流しながら，二酸化炭素の濃度をい ろいろ变化させ，そのとき吸光度を測定したが Fig. 3 に示すように二酸化炭素による影響はほとんど認められ なかった・

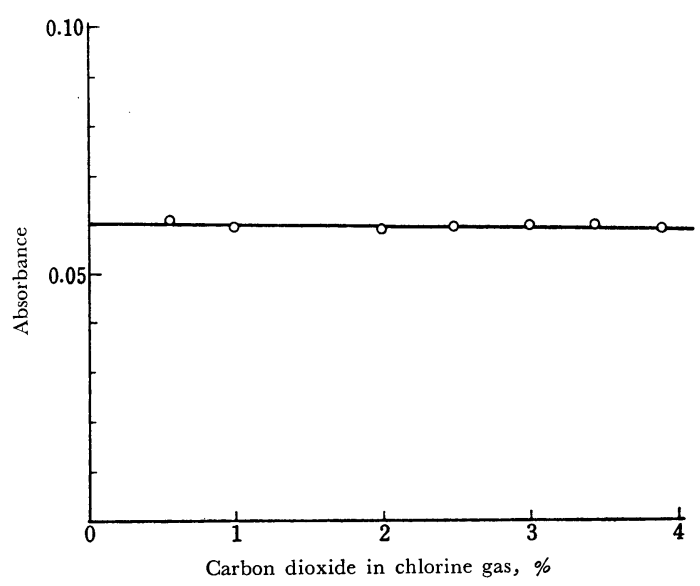

Fig. 3 Influence of carbon dioxide on the determination of hydrogen in chlorine gas

\section{6 検量線の作成}

$3 \cdot 1$ の方法で水素と塩素の混合比すなわち水素濃度を いろいろ変化させ，水銀燈で照射されたガスを赤外用ガ

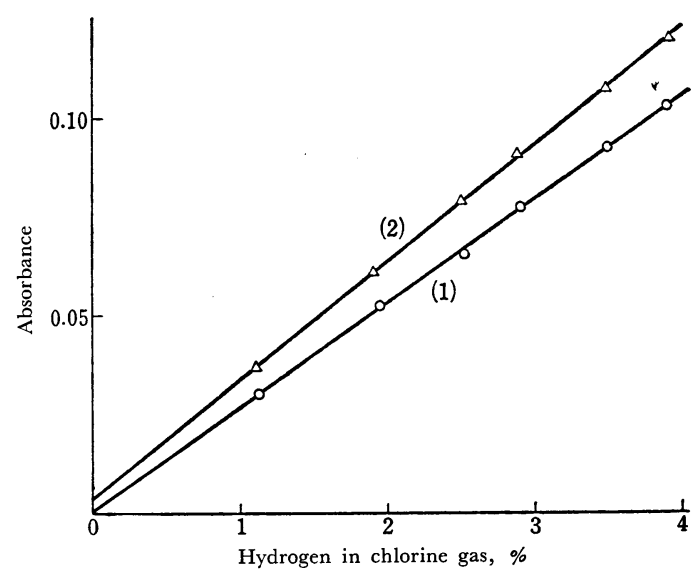

Fig. 4 Calibration curves of hydrogen at $2840 \mathrm{~cm}^{-1}$ (1) and $2980 \mathrm{~cm}^{-1}$ (2) 
スセルにとり，3.3 の方法で吸光度を測定して検量線を 描いたが，Fig. 4 に示すように $2840 \mathrm{~cm}^{-1}$ と $2980 \mathrm{~cm}^{-1}$ における検量線はそれぞれ直線を示し，それらの回帰 分析による回帰式は (1) $y=5.986 \times 10^{-2}+2.587 \times 10^{-2}$ $(x-2.267)\left(2840 \mathrm{~cm}^{-1}\right) ;$ (2) $y=7.143 \times 10^{-2}+2.971$ $\times 10^{-2}(x-2.267)\left(2980 \mathrm{~cm}^{-1}\right)$ である.

なお検量線（1)，(2) の実測値とそれぞれの回帰式よ り求めた吸光度を比較すると Table I になる。

Table I Absorption from calibration curves (1) and (2), and that from regression formulas

\begin{tabular}{|c|c|c|c|c|}
\hline \multirow{3}{*}{$\mathrm{H}_{2}(\%)$} & \multicolumn{4}{|c|}{ Absorbance } \\
\hline & \multicolumn{2}{|c|}{ Calibration curve } & \multicolumn{2}{|c|}{ Regression formula } \\
\hline & (1) & (2) & (1) & (2) \\
\hline 0.00 & 0.002 & 0.004 & 0.001 & 0.004 \\
\hline 1.13 & 0.030 & 0.038 & 0.030 & 0.038 \\
\hline 1.98 & 0.052 & 0.063 & 0.052 & 0.063 \\
\hline 2.54 & 0.065 & 0.080 & 0.067 & 0.080 \\
\hline 2.90 & 0.078 & 0.089 & 0.076 & 0.090 \\
\hline 3.50 & 0.091 & 0.107 & 0.092 & 0.108 \\
\hline 3.82 & 0.101 & 0.119 & 0.100 & 0.118 \\
\hline
\end{tabular}

\section{4 応用と結果}

\section{1 応用}

Fig. 5 の装置で食塩電解そうから出た塩素ガス中の水 素の定量を行なった・すなわち電解そうから出たガスは 相当の水分を含えでいるので，まず冷却脱水装置（B） （本実験ではジムロート冷却器を用いた）で脱水し，つ いでシリカゲル乾燥塔 (D) を通し, リフォレンスセル （H）を通してから石英ガラス管（F）に導き，ここで

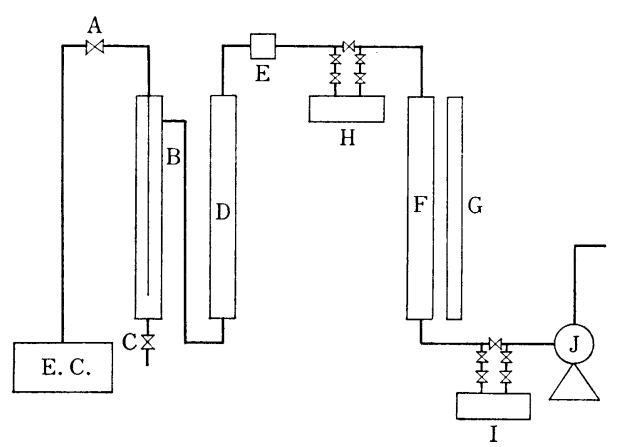

Fig. 5 Schematic diagram of apparatus for determination of electrogenerated chlorine gas E. C. : Electrolytic cell; A : Inlet of sample gas; B : Cooling trap; C : Drain ; D : Silica gel dryer; E : Back stopper; F : Quartz reactor tube; G : 400W mercury lamp (Toshiba H400P); H : Reference cell; I : Sample cell; J : Pump
水銀燈（G）で照射する. 照射されたガスをガスセル （I）で捕そくし，Hを対照に吸収曲線を描き，基線法に よって吸光度を算出し, 一方 3.1 の装置で得られた検量 線より水素濃度を算出した。

\section{2 結 果}

$4 \cdot 1$ による方法で食塩電解そうより発生する塩素ガス 中の水素量を求め, 同時に従来常用されている爆発法に よる水素ガスの定量值と比較した。これを Table II に 示す.

Table II Determination of hydrogen in chlorine gas

\begin{tabular}{cccc}
\hline \multirow{2}{*}{ Exp. No. } & \multicolumn{2}{c}{ This method } & $\begin{array}{c}\text { Explosion } \\
\text { method } \\
\mathbf{H}_{2}(\%)\end{array}$ \\
\hline 1 & Absorption & $\mathrm{H}_{2}(\%)$ & 1.05 \\
2 & 0.0353 & 1.04 & 1.00 \\
3 & 0.0329 & 0.96 & 0.48 \\
4 & 0.1950 & 0.47 & 0.66 \\
5 & 0.0229 & 0.64 & 1.18 \\
\hline
\end{tabular}

Table II からも明らかなようによく一致した值が 得られた。

$$
5 \text { 結 言 }
$$

塩素中の水素は，水銀燈を照射したのち赤外分光光度 法を用いて生じた塩化水素の吸収を測定することにより 定量可能である.この方法は水分，二酸化炭素の影響が ないので, 電解そうを出た状態の塩素中の水素の定量に 適当であると考えら机る. また二酸化炭素の吸収領域と 異なっているので，塩素中の水素と二酸化炭素の同時測 定も可能であり，適当な赤外線分析計と組み合わせれば 連続化への可能性もある.

終わりに，ご助言を賜わった東亜合成化学工業(侏取締 役永多保信徳島工場長, 実験に協力された清水紀子, 福 本佳子両学士に感謝する.

$\left(\begin{array}{l}\text { 昭和 } 40 \text { 年 } 10 \text { 月，第 } 21 \text { 回日 } \\ \text { 本薬学大会において一部発表 }\end{array}\right)$

\section{交献}

1) 堺 健, 江口 敏 : 特許公告, No. 3850(1958).

2) 下村 滋, 福本佳子 : 徳大薬研, 15, 11 (1966).

$$
\text { is }
$$

Determination of hydrogen in chlorine gases. Shigeru ShimomurA* and Masao IGUCHI** (Faculty of Pharmaceutical Sciences, University of Tokushima, Shō-machi, Tokushima-shi ; **Tōagōsei Chemical Industrial Co. Ltd., Tokushima Factory, Kawauchicho, Tokushima-shi) 
An infrared spectrophotometric method for the determination of hydrogen in chlorine gas was proposed. Sample gas was exposed to the photochemically active light in a quartz reactor tube, to form hydrogen chloride by the reaction $\mathrm{Cl}_{2}+\mathrm{H}_{2} \stackrel{\mathrm{h} \nu}{\longrightarrow}$ $2 \mathrm{HCl}$. Then the reaction gas was led into a $100 \mathrm{~mm}$ I. R. gas cell, and the absorption from $3400 \mathrm{~cm}^{-1}$ to $2400 \mathrm{~cm}^{-1}$ was measured by an infrared spectrophotometer.

The absorbance at $2980 \mathrm{~cm}^{-1}$ on $2840 \mathrm{~cm}^{-1}$, each a maximum of saw toothed absorption curve of hydrogen chloride, was calculated by the use of base line method. Since water and carbon dioxide did not interfere at those wavenumbers, the method was suitable for the determination of hydrogen in electrogenerated chlorine gas. The values of hydrogen contents in electrogenerated chlorine determined by this method were well congruent with those obtained by the more complicated explosion method.

(Received Feb. 5, 1968)

\title{
チアミンによる銅の新けい光定性分析法*
}

\author{
山根”靖弘，山田 洋子，国弘茂**
}

\begin{abstract}
本分析法は，著者らがさきに見いだした塩酸チアミンすなわちビタミン $\mathrm{B}_{1}$ のチオール型が銅イオン と反応してあざやかな赤色けい光を発することを応用したものである.第二銅および第一銅イオンもと もに本反応にあずかるが，第一銅イオンのほうがよりけい光が強い.

試料溶液に塩酸ヒドロキシルフミンを加え，フルカリで $\mathrm{pH}$ 約 7 に調整し検液とする。これにチオー ル型チアミン試液を加えて生ずる赤色けい光を長波長の紫外線で観察する．上記反応を沪紙上で行なう スポットテスト法と，そのけい光物質をイソフミルアルコールで抽出する抽出法とを確立した.

この赤色けい光は銅イオンに特異的であり，またほかのイオンが共存しても消光的妨害を受けにくい.

確認限界はスポットテスト法に拈てて 1 滴中 $0.3 \mu \mathrm{g}$, 抽出法において $1 \mathrm{ml}$ 中 $6 \mu \mathrm{g}$ でる. な お，けい光の安定性は抽出法のほうがややすぐれている.
\end{abstract}

\section{1 緒馬}

著者らはさきに，塭酸チアミンすなわちビタミン $\mathrm{B}_{1}$ 塩酸塩のチオール型化合物が銅イオンと反応しあざやか な赤色けい光を発することを見いだし1) 3)，このけい光 性を塩酸チアミンの分析に応用した4).

今回本反応を銅イオンの定性分析法に応用したとこ ろ，美しく見やすい赤色けい光が現われ，非常に感度が よく，従来銅イオンの定性分析に用いられているベンゾ インオキシムあるいはサリチルアルドキシム法5) 程度の 感度を有すること，またほかの金属ではほとえどこのよ うな赤色けい光が現われないこと，さらに共存物質の影 響を受けにくいなどの点において，分析上じゅうぶえ価 值あることが認められたのでここに報告する。

\section{2 試薬および装置}

\section{1 試 薬}

チアミン試液：塩酸チアミン（ビタミン $\mathrm{B}_{1}$ 塩酸塩,

*チアミンによる銅のけい光分析（第1 報）

** 千葉大学薬学部衛生化学教室 : 千葉市弥生町
武田薬品）を水一アセトンにより精製し，本品 $0.05 \mathrm{~g}$ を 水に溶かして全量 $100 \mathrm{ml}$ とする. この液に $1 N$ 水酸 化ナトリウム液を加え $\mathrm{pH} 10 \sim 11$ とし, 室温で約 30 分間放置後チオール型チアミン試液とし使用する．この 試液は用時調製する。

$20 \%$ 水酸化ナトリウム液：試薬特級水酸化ナトリウ ム $20 \mathrm{~g}$ を水に溶かして $100 \mathrm{ml}$ とする.

$1 N$ 水酸化ナトリウム液: 試薬特級水酸化ナトリウム $4.3 \mathrm{~g}$ を水に溶かして $100 \mathrm{ml}$ とする.

塩酸ヒドロキシルアミン：試薬特級を用いる。

イソアミルアルコール：試薬特級を用い, あらかじめ 盲けい光のないことを確かめておく.

無水硫酸ナトリウム：試薬特級を用いる.

第二銅標準溶液 : 試薬特級硫酸銅 (5 水塩) $400 \mathrm{mg}$ を 水に溶かして $1000 \mathrm{ml}$ とする. 本原液 $1 \mathrm{ml}$ は $100 \mu \mathrm{g}$ の銅を含む．本液を適当に希䣋して標準溶液とする。

第一銅標準溶液 : 上記第二銅標準溶液 $5 \mathrm{ml}$ に塩酸七 ドロキシルアミン $1 \mathrm{~g}$ を加え, $20 \%$ 水酸化ナトリウム 液で $\mathrm{pH}$ を約 7 としたのち，これに水を加えて $10 \mathrm{ml}$ とする.

\section{2 装}

紫外線発生装置としては長波長 $(3650 \AA)$ のマナスル 